\title{
One supervisor, two students: Experiences and anxieties of PhD journeys
}

\begin{tabular}{|c|c|}
\hline \multicolumn{2}{|c|}{$\begin{array}{l}\text { Authors: } \\
\text { Muchativugwa L. Hove }{ }^{1} \\
\text { Paul N. Nkamta }\end{array}$} \\
\hline \multicolumn{2}{|c|}{$\begin{array}{l}\text { Affiliations: } \\
{ }^{1} \text { Faculty of Education, School } \\
\text { of Undergraduate Studies, } \\
\text { North-West University, } \\
\text { Mafikeng Campus, } \\
\text { South Africa }\end{array}$} \\
\hline \multicolumn{2}{|c|}{$\begin{array}{l}{ }^{2} \text { Department of English, } \\
\text { School of Human Sciences, } \\
\text { North-West University, } \\
\text { Mafikeng Campus, } \\
\text { South Africa }\end{array}$} \\
\hline \multicolumn{2}{|c|}{$\begin{array}{l}\text { Corresponding author: } \\
\text { Paul Nkamta, } \\
\text { paulnepaps@yahoo.com }\end{array}$} \\
\hline $\begin{array}{l}\text { Dates: } \\
\text { Received: } 25 \\
\text { Accepted: } 13 \\
\text { Published: } 17\end{array}$ & $\begin{array}{l}\text { Apr. } 2016 \\
\text { Oct. } 2016 \\
\text { Feb. } 2017\end{array}$ \\
\hline \multicolumn{2}{|c|}{$\begin{array}{l}\text { How to cite this article: } \\
\text { Hove, M.L. \& Nkamta, P.N., } \\
\text { 2017, 'One supervisor, two } \\
\text { students: Experiences and } \\
\text { anxieties of PhD journeys', } \\
\text { The Journal for } \\
\text { Transdiciplinary Research in } \\
\text { Southern Africa 13(1), a340. } \\
\text { https://doi.org/10.4102/ } \\
\text { td.v13i1.340 }\end{array}$} \\
\hline \multicolumn{2}{|c|}{$\begin{array}{l}\text { Copyright: } \\
\text { (C) 2017. The Authors. } \\
\text { Licensee: AOSIS. This n } \\
\text { is licensed under the } \\
\text { Creative Commons } \\
\text { Attribution License. }\end{array}$} \\
\hline \multicolumn{2}{|c|}{ Read online: } \\
\hline 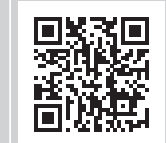 & $\begin{array}{l}\text { Scan this QR } \\
\text { code with your } \\
\text { smart phone or } \\
\text { mobile device } \\
\text { to read online. }\end{array}$ \\
\hline
\end{tabular}

Today, colleges and universities offer master's and doctoral degrees in increasing numbers. Many students enrol in these programmes and, in many cases, such students are without appropriate guidance and support in conceptualising, conducting and writing original research. The lack of support and guidance during the M\&D journey results in students taking more than the required duration for the programme, withdrawal or abandonment and, consequently, a drop in the number of completed theses and dissertations at colleges and universities. This article adopts a diaristic approach to document and examine the experiences of two PhD students at an institution of higher learning in South Africa. It seeks to demystify the notion that PhD studies are for a select few and proffers to chart some ways towards the successful completion of M\&D studies.

\section{Introduction}

This article interrogates the concept of doctorateness as the acquisition of a scholar's transformed capabilities in the conceptualisation of a specific research problem. The article engages the metaphor of journeying towards a horizon in order to signal the strides that push forward the boundaries of knowledge evidenced in the originality and systematicity of doctoral studies. Keefer (2015:18) extends the journey motif and argues that doctoral students face numerous challenges along the path towards doctorateness, adding that doctoral liminality is the in-between period filled with uncertainty and anxiety, specifically because it is also a period of identity construction. Along this journey, agency resides in both the supervisor and the student: the supervisor models the student in their discipline; the student constructs a new identity matrix spurred by personal and academic intentions.

\section{The PhD journey: Theoretical framework}

The doctoral journey commences with the selection of an appropriate topic where the researcher has identified a gap that he or she wishes to fill through undertaking quantitative, qualitative or mixed methods research. Identifying a topic is a messy undertaking in a digitised world, where 'almost everything' has been written about by both novice and professional. When such 'everything' is immediately disseminated to global audiences through websites and journal platforms, it is also increasingly difficult to identify specific gaps that need to be filled in. This often leads inexorably to an inarticulate preliminary area of research, where the student seeks to find space for 'belonging' and a process of 'conscientious stylising' connects to commitment and representation in the academy. The supervisor, a key companion on this research process, adds a special patina to the enquiries and displays various styles of supervision conceptually imagined in Figure 1.

McAleese and Welsh (1983) suggest that few masters and doctoral students prefer the cold and free supervisor principally because such a mentor is aloof even though they might provide academic direction and keep students on track. The supervisor, in being a key companion on the doctoral journey, invariably belongs to a small coterie of academic 'gatekeepers', some of whom find a nebulous but vindictive pleasure in asserting their authority in a discipline to the extent that 'admission' into their community of scholarship is jealously protected. Using the metaphor of 'a journey', Miller and Brimicombe (cited in Turner 2015:87) maintain that experience can be likened to a journey where an individual, alone or accompanied, 'is moving from one place to another', over time. This journey involves endings and beginnings, is sometimes into the unknown and can entail loss and retrieval, change and renewal, and disorientation and displacement (Batchelor \& Di Napoli 2006). Thus, recounting a journey can identify important aspects such as milestones and events, uncover the emotions, intensity, complexity, impact and meaning involved, and promote self-awareness and problem-solving (Turner 2015:87). The warm and structured 


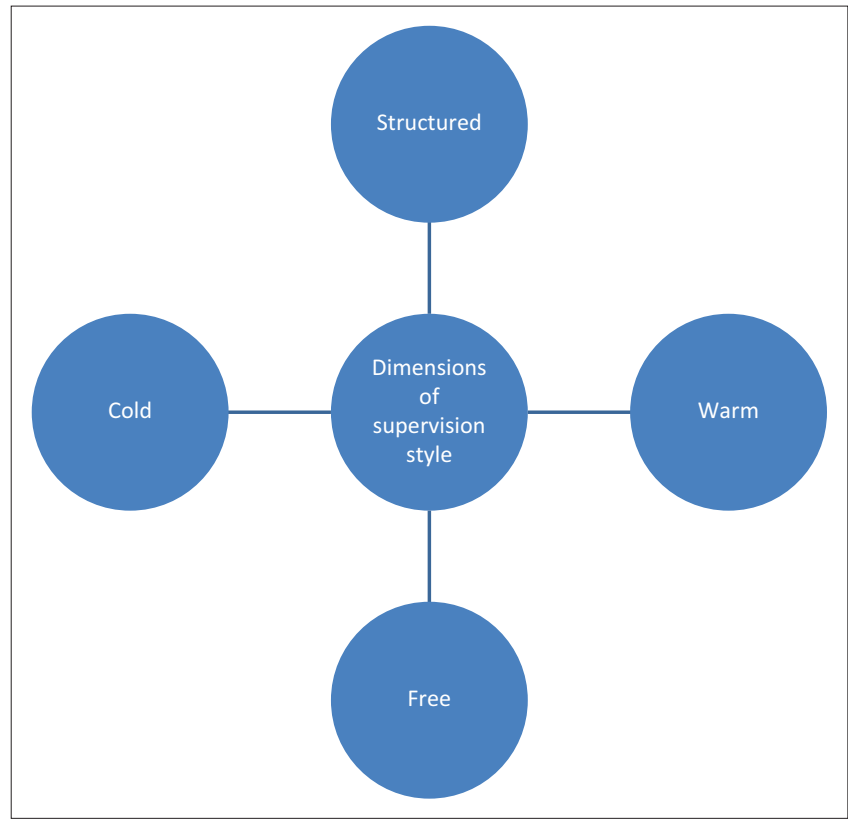

FIGURE 1: Conceptualisation of supervision styles.

supervisor provides, quite often, succinct and professional guidance. Although this might be a generalisation, often, the warm and structured supervisor has subject content expertise and is often available to provide stimulating help. This partly explains why the journeys of the two students reported in this article make a contribution towards understanding the doctoral journey: the two were foreign nationals in South Africa who had settled in their individual proposals what they conceptualised as research terrain that would amount to authentic representation. In addition, both students recognised that gaining the access codes into this academy implied an efficient single-mindedness and confident sense of academic identity development.

In providing professional guidance, rapport is built between the supervisor and the student. Blumer (1969) refers to this relationship as 'symbolic interaction', a particular form of interaction that occurs between persons. He maintains:

The peculiarities consist in the fact that human beings interpret or 'define' each other's actions instead of merely reacting to each other's actions. Their 'response' is not made directly to the actions of one another but instead, is based on the meanings which they attach to such actions. (p. 19)

\section{Support and guidance}

Table 1 draws on the reported relationships between supervisors and M\&D students. Brown and Atkins (1988) provide a framework for the categories listed here.

The table presents some terms that are quite controversial in light of Freire's arguments in Pedagogy of the Oppressed where any conceptualisation of the student as passive recipient and tabula rasa who brings in no experiences and knowledge are fraught with inadequacies (Freire 1972:37). Our narratives of doctoral journeys under one supervisor seek to broker transformative positions at the nexus between
TABLE 1: Relationships between supervisors and students.

\begin{tabular}{ll}
\hline Supervisor & Student \\
\hline Director & Follower \\
Master & Servant \\
Guru & Disciple \\
Teacher & Pupil \\
Expert & Novice \\
Guide & Explorer \\
Project manager & Team worker \\
Auditor & Client \\
Editor & Author \\
Counsellor & Client \\
Doctor & Patient \\
Senior partner & Junior professional \\
Colleague & Colleague \\
Friend & Friend \\
\hline
\end{tabular}

the supervisor and the 'emerging researcher' who is the student.

The supervisor has varied and challenging roles in the research process, some of which are identified and amplified here.

- Director: Interrogating and approving the research topic and the appropriateness of selected research methods.

- Facilitator: Helping to resolve technical, scientific and methodological problems and also providing alternative epistemic directions on controversial issues.

- Teacher: Honing research techniques adopted by the researcher and advising on recent sources of literature for depth and breadth of the niche area.

- Guide: Suggesting timeframes for writing-up, giving constructive feedback on progress and ultimately providing critical paths for data collection, analysis and evaluation.

- Critic: Reflective suggestions on the design of research enquiry, draft chapters and interpretation of data.

- Freedom giver: Authorises research students to make academic decisions and supports such decisions based on the audacity of the decisions as they develop new contours and horizons of knowledge in the field. Walter Mignolo (2015:7) calls such audacity in search for constructed and situated knowledges 'epistemic disobedience'.

- Supporter: Gives encouragement, shows interest and discusses student's ideas with relish.

- Friend: Extends interest and concern to non-academic aspects of research student's life.

- Manager: Checks progress regularly, monitors the study, gives systematic feedback and plans fora to tease out challenges in a scholarly manner.

- Examiner: The supervisor is an internal examiner who adjudicates quality of the research and recommends for external evaluation on the singular criterion of the robust quality of the research processes and ultimate product.

Corbin and Strauss (2008:15) maintain that 'persons do research because they have a dream that somehow they will make a difference in the world through the insights and understandings they arrive at'. This dream can only be 
achieved upon completion of the studies. Dreams must therefore be brought to fruition (2008).

\section{Challenges faced during the journey}

This article is based on the understanding that although there are multiple experiences that candidates go through during their PhD journeys, there is one common goal in sight - finishing and submitting the study ('getting the damn thing done!'). Turner (2015:87) believes when a journey is related to others, it can act as a map for those embarking on something similar. At the PhD level, however, 'getting the damn thing done' entails an increased depth and research rigour that culminates not just in a doctoral graduate, but that refined and ineluctable quality of academic finesse one could call 'doctorateness'. Corbin and Strauss (2008:21) contend that one of the most difficult aspects of doing research is deciding upon a topic for investigation. They maintain that the topic is something the researcher lives with for some time; so it has to be topical, interesting and offering possibilities for exploration.

Corbin and Strauss (2008) argue that the two major questions related to deciding upon a topic are the following:

1. How do I identify a problem that I would like to research?

2. How then do I narrow the problem down sufficiently to make it into a workable doctoral project?

Kapp (2014) also adds his observations on the challenges of identifying a researchable topic that has to be narrowed down. This entails a systematic review of the current state of knowledge in the niche area, including an ability to critique the work of other scholars. The research problem must, willy-nilly, address a specified knowledge gap through an appropriate method conforming to disciplinary understandings of research. Kapp (2014) admits that at D-level, the researcher ought to demonstrate expertise in the search for new epistemological horizons and that such a quest demands robust conceptualisations of the research initiative. D-level research, according to Kapp (2014:1), must demonstrate innovative research paths leading into specialised and complex systems that are characteristically intense processes of analysis and synthesis, and oftentimes abstract.

\section{Experiences and states of anxiety}

This article searches for the meaning of doctorateness through unpacking the voices of two students under one supervisor. Narrative enquiry is a methodological approach that seeks to purposively identify and understand the cameos and stories that research participants privilege about their experiences and perspectives (Creswell 2013). The liminality of doctorateness for the research participants in this article invites reflexivity, retrospection and introspection where troubling experiences connected to uncertainty, loneliness and excitement are storied.

\section{Ethical considerations}

All research participants in this research have been anonymised and no institutions have been exposed to protect their identities.

\section{Motsha's journey}

Motsha held a joint master's degree in literature in English and English as a second language from a prestigious African university. He had done exceptionally well in the literary components, specifically African American Literature and ideological thought and African literature and ideological thought. On meeting Prof., Motsha hinted at a proposal for PhD candidature and was advised to provide a 20-page write-up. Enthusiasm and self-confidence were high and, in September 2008, Motsha submitted 'Routes and roots: Strategies of representation and cultural dissemination in African literary theories'. This proposal sought to add to the contestations on what constitutes African literature and the theoretical moorings of many-a-critic's enunciation on the critical precepts and tools and functions of such theories. Although many universities today proudly tout multidisciplinarity as their flagship status, this 'borderless' mantra is an overstatement: many institutions of higher learning are notoriously and pervasively plagued by monological disciplinary silos, overly protecting their 'fragilising' commitments rather than admitting novices who desire to participate differently. I waited with baited breath for the nod to proceed with the chapters I had outlined.

Two months from the day of submission, with some degree of temerity, I called to find out what the decision was. Prof. advised I should meet to confer in his office at five in the evening. He was not keen to supervise some 'abstract theories that do not contribute to language challenges in the South African classroom'. He insisted that at the end of a PhD journey, 'you must present something that works ... something you should proudly say, "Here, this is my product"'. In some margin of the first page of the 'Routes and roots' proposal was a pencilled comment, 'This is a credible and sound proposal but ...' I had written 20 pages of a proposal and Prof. had read the first five, a trend that was to be a patent of Prof.'s feedback in the copious drafts of my thesis. I was seething inside: this was an area that I had read around and knew so much about. I had a meticulous record of intentions, methods and evidence and was ready to make recommendations about constructing narratives that provide a multiplicity of identities. In a sly wink of the eye, Prof. suggested that I should look at something 'worthwhile at your school'. I slunk out of his office, dazed by a potential supervisor who had 'diagnosed deficiencies' in my proposal and was going to be 'a critical, controlling taskmaster' (Kapp 2014:9). For some time, I felt so disadvantaged and lacking empowerment; I was on the fringes of a discursive community that appeared hostile to enquiring into contested territory. 
I was determined to pursue theorising narrative constructions that project the self ... auto/biography. Three years later, in 2012, that same proposal was accepted by Palgrave MacMillan as a monograph and got eventually published in 2014 as Strategies of representation in auto/biography: Reconstructing and remembering. To some extent, I felt vindicated: that was the D-thesis that I had always wanted to re-search about.

In 2009, I was surprised by a call from Prof. asking about my new proposal. I lied and indicated I was working on it. Meanwhile, the private school I was teaching at had just enrolled a group of 31 students from previously disadvantaged schools. I mulled over the idea of a syllabus development project that would serve as an acculturation study and investigate the role of multilingualism. Eureka! I had a research problem that would assuage my supervisor's somewhat narrow conceptualisation of 'contributing productively to the discipline'. Perhaps this 'necessary barrier' and Prof.'s 'expertise in other fields' was to facilitate my negotiation of massive tomes of literature in English language pedagogy in a multilingual case-study setting. I narrowed my research to basic interpersonal communication (BICS) and cognitive academic language proficiency (CALP) skills, after Cummins (1994) and then spent countless nights screening the literature for its comprehensiveness, authority and relevance as I began to find both presence and voice. I so much wanted to avoid regurgitation of ideas through critical engagement with syllabus designers, perspectives on language learning and scholars on multiple literacies. The following were my research questions and objectives:

What effective, relevant and efficient English language syllabus could be designed for L2 learners in order to empower them with cognitive academic language proficiency skills, enabling them to succeed in the multiple discourses embedded in their secondary schooling at a private school in South Africa?

In terms of significance:

1. This study sought to establish the feasibility and sustainability of such a programme as undertaken by the sponsor, the Telkom Foundation, describe the learners' competencies at entry and exit points and make recommendations to the department of education, the sponsors and other stakeholders, particularly the private school case study context in South Africa. Because each case study develops around the unique attributes of the sample, the syllabus developed applied to the unique challenges, circumstances, transitions and strategically developing competencies of the research participants in question.

2. I reviewed literature on mother tongue instruction, language immersion programmes and the ESL pedagogical strategies used to enhance mastery and competence in language. I analysed policy and practice in language education in South Africa in order to place this qualitative study within a broader context of bridging the educational divide between privileged and underprivileged educational sites, first language and second language user competencies, urban and rural communities.

3. North-West province, in which the private school is located, is a province on the margins. There are a number of disadvantaged schools that could benefit from the spin-offs of this study should the integration, academic and linguistic empowerment of the students in this study succeed.

4. Competence in language is a critical facility for academic progress: learners have to reason in multiple discourses in order to comprehend, write, analyse and evaluate questions and issues. This study focused on a crucial secondary school stage, with learners aged between 13 and 16 years, and it was expected that the findings on language learning strategies at this grade level would be a significant contribution to language learning and development.

Accepting the fact that the learners in this study could perform at the level of the 'reproduction cluster' and that they could perform routine procedures and problem-solving at the basic language level, the anticipated syllabus should enable the learners to go through a programme of language study culminating in them operating at the 'connections' and 'reflection' cluster level. These are levels where application skills, reflection, generalisation and generation of interpretive and analytical modes become actualised as academic language capacities in the learners.

English language syllabus design was not a new area of research, but it was the extent of the development of academic literacy skills that was riddled with tensions. This was going to be my contribution to knowledge in applied language studies: an analysis of the learners' needs and implementation of the syllabus designed in situ. At many a point in the formulation of the research problem, this study mediated issues in multilingualism, assessment, discourse analysis and the politics of poverty and underdevelopment. I had to exercise extreme caution in selecting relevant approaches; otherwise, I would have risked becoming descriptive without the essential depth of focusing on a specific issue and, consequently, dealing with disparate matters. In the longitudinal case study that sought to devise a contextually efficient syllabus aimed at empowering learners from previously disadvantaged schools, I realised that this was not just another 'research to fill a gap', but one entangled in the politics of transformation, one that sought profound improvement in the metrics and indices of success in a language curriculum that determined the upward trajectory of 53 learners, and more. Much later, one of the three external examiners of my study noticed these tensions and lauded the manner in which they had been dealt with:

The candidate's planning and execution of the process of gathering materials using the qualitative design as the main method has been up to standard. The data collection procedures, the hypotaxis index and the classroom delivery strategies leading to specific language skills, to the validation and reliability of the 
entire information ... demonstrate the candidate's ability to deal with multiple concerns connected to this thesis. (External Examiner's Report 2011:2)

Prof.'s comments earlier on had identified narrowness in my literature review. I recall an unflattering comment related to my review of Cummins' distinctions between BICS and CALP:

'Literature abounds with studies that have seriously criticised Cummins' use of these terms ... It is incorrect to perceive, as Cummins does, that the acquisition of these skills is sequential ... I expect a critical perspective of this theory and you should not treat them as the "Bible" truth. Consider also the role of transfer of academic skills acquired in students' L1 to L2 since your cohort is made up of multilingual learners ...'

Indeed, there was massive literature on distinctions between 'conversational' proficiency and 'academic' proficiency but none of this seemed to focus on multilingual learners, and the problems I had identified in learners weaned from one syllabus - the Outcomes-Based Syllabus in South Africa - to the International General Certificate in Secondary Education. This meant teasing out the complexities associated with syllabus transition, and this necessitated a comparative approach negotiated through observation and triangulation.

I resolved to have two Literature Review chapters: one on curriculum-syllabus design, implementation and evaluation, and the other on review of language skills and competencies in multilingual contexts. At the end, I proposed a framework for syllabus design based on the longitudinal case study, keeping in mind the admonition from Prof. that he expected a critical perspective ... a critical perspective. That phrase haunted me. I tore into Bakhtin's dialogical perspectives on double-voicedness and polyphony, Smitherman's Talkin' and Testifyin' (1977), Phillipson's Linguistic Imperialism (1992), Gee's Linguistics and Literacies (1990), Canagarajah's Towards a Writing Pedagogy of Shuttling between Languages: Learning from Multilingual Writers (2006), Blommaert's Discourse: A Critical Introduction (2005), Janks' Literacy and Power (2010) and other recent publications that interrogated the vexed issues on multivocality and black discourses. Although they were eminent scholars in their own right, they treated my research concerns only tangentially, perhaps giving different emphasis, and I had to find the elusive centre that would show how black students from multilingual Englishimpoverished contexts become deprived in multiple ways when they enter English medium schools and they had to compete with students from middle-class backgrounds. I kept searching for the kind of multilingual discursive and pedagogic practices that could promote context-sensitive academic registers in the English language classroom. And somewhere in Teaching Other People's Children, Delpit (1995; 2006) contends that proficiency in writing academically is the litmus test that allows access to the cultural capital and enables upward socio-economic mobility. That was my thesis.
In this literature search, I experienced some academic déjà vu in encountering Smitherman and Janks and Delpit (1995; 2006), a kind of intellectual kinship involving similarity in the manner in which facts are assessed, comprehended and valued. It was a sensation which began to reside in me when, immediately upon reading their academic papers, it seemed as though I had always been tied to them by an enduring intellectual friendship. I so much wanted some 'southern' theoretical platform that contested 'northern' projects. This state of intellectual kinship provoked the feeling of finding myself immersed in a pleasant ambience in which intercultural communication takes place with a minimum of disturbances, an ambience in which the English language themes discussed have been learned by both individuals through similar epistemological approximations. Ridge (2015:132) writing about 'transformation and the role of the intellectual' admits that 'when we become too comfortable with words, we let them hide reality from us'. In South Africa, transformational and intellectual challenges in English language education are sorely real, and the indices of change should open opportunities for black South Africans to participate, through informed curiosity, in the manner in which the language is taught and learned. Illiteracy is a deprivation. The profound heritage of disadvantage among black South Africans has been differently documented. And the immense inequalities in educational opportunities that constrain the lives of the subaltern urgently call for an academic economy of obligation on researchers and teachers.

I was embarking on an intellectualisation and abstraction of my pedagogic world in order to aid comprehension of multilingual classrooms. I was going to submit an intellectual structure in the form of a model that would be used to understand language concepts and how these functioned and related to one another in very troubled ways. And Prof. insisted each time we met late in the night that I had to distinguish key bodies of literature: theoretical, empirical and evaluative, as well as the key debates in which key scholars were entangled. Out of these critical conversations, I found that some of the comments were ambiguous and instead of being reinforcements, many a time, they were bland questions such as 'What do you mean?' If my Prof. did not understand what I meant, then I had to seriously reflect on this challenge. I was hounded throughout by this fuzzy concept of 'doctorateness' to which I had ascribed meanings such as refreshingly original, eminent, influential and very knowledgeable. I sought to shelve my hurt and search for clarification from 'authoritative sources' on the internet, the library and the one colleague who was also enrolled on a $\mathrm{PhD}$ programme at the same institution.

I was confident that there were challenges in and of English Language teaching in South Africa, especially at the expensive multiracial, multi-ethnic and multi-languaged school at which I taught. As an academic, I sought to engage in meaningful dialogue with the real-life contradictions in the translingual practices at the research site: I had to hold the local and global demands in some creative tension in order to develop a 
pedagogy that was not based on a deficiency model of my students. I outlined the challenges as detailed below.

\section{Language and age}

One of the perennial challenges in and of English Language teaching at foundation phase in South Africa relates to the transition from L1 to L2. Language practitioners and applied language specialists are not unanimous on the appropriate age at which learners could begin learning an additional language. As a consequence of controversies in this regard, many South African children go to preschool from such tender ages as 2 and 3 where they are immediately 'nursed' in English. Quite often, such children have not fully acquired the optimal language proficiency in their own L1. To a large extent, these children fumble with the twin language repertoires that they have to gain competence in. They need to be able to 'say after me', to copy out correctly, to spell in conventional ways for mutual intelligibility, and as they learn to tell their own biographies, they should remember there is always an audience.

\section{Phonics and enunciation}

Language proficiency entails listening, speaking, reading and writing. At the foundation and early secondary school phase, fluency and phonetics are critical aspects. Pronunciation, articulation and voice are principal focus areas and parents are encouraged when they collect their children from preschool centres and primary school sites and they hear them speak in English, in some newly acquired accents. Should these children speak to their parents in their home language, then the schools and centres are perceived as not teaching the children anything of value. There is a problem when parents insist on instruction and learning 'English only' and 'Afrikaans only'.

\section{Structures and skills}

Later in the progression of the learners from lower grades to higher ones, new tensions in language practices emerge: accuracy versus sense-making, and speaking versus writing. Many of the challenges that learners encounter relate to the early foundations of literacy and how this quality is accessed. From local contexts, they should be taught to read with relish and seek connections to extended boundaries ... the global. As teachers at the early secondary school level, what stories should our learners be exposed to? What levels of language complexity and usage would I need to expose my research participants to in order for them to gain access into varieties that would allow access to meanings and layers of meanings embedded in texts? It has long been established in learning theories that we start from the familiar and extend to new horizons. It is daring to state that the foundations of literacy are in language and the solid base is the ability to reason and make inferences and offer evaluative comments in a specific language. Thus, reading and writing become privileged abilities.

\section{Language modelling}

Language learning is imitative: the teacher in foundation phase and early secondary school is always in the role of a model. This modelling challenge remains critical in language learning, mastery, articulation and ultimate competence, particularly competence in the reading and writing aspects that eventually are nurtured into academic language proficiency. In principle, what is taught incorrectly by models (the teachers and peers) is difficult to erase, more so if any corrective feedback happens when the incorrect concepts have fossilised.

In an age that has morphed into e-sites, e-text, e-language and such other e-platforms, literacy spaces have been invaded. Early exposure to such e-platforms has been anecdotally described as having debilitating consequences on language learning and subsequent competence. Spelling errors, grammaticality of sentences and even the structural boundaries of sentences have all been somewhat influenced by these platforms and exposure to such platforms. Scholars have submitted that mothers who spend enormous time on e-platforms such as Facebook and WhatsApp risk having their children 'unlearn' language ... the children born to such addicted mothers will soon learn to laugh, smile and swear ... because that is the only language to which they are exposed to. Ironically, or in spite of this, we were at a research site that promoted e-learning, blended platforms and utilisation of e-resources.

\section{Multilingualism and translingual practices}

In South Africa, multilingualism is a resource that ought to be brought into the teaching and learning of language and its indexicality in the negotiation of identities. Conversations on mobility, integration, hybridity, the local and the global are all suffused with the importance of language skills: to speak, and read, and write is to exist for the other. In the carnival of recent civil unrest that played out as xenophobia in 2008 and 2015 in South Africa, there was tangible and irrefutable evidence that creating language silos and language compartments was certainly perceived as analogous to apartheid legislation, which indeed pointed to glaring slippages in the national transformation project. In the foundation phase, the challenges of language learning have to be discursively situated within the overarching debates of inclusion and exclusion, upward socio-economic mobility and negotiating identities for the future. What is critically important is not just a language toolkit, but structures and skills that allow for analytic, evaluative and synthetic skills. Right at the foundation level, learners can analyse and evaluate statements at grade-appropriate skill levels. The small flattering or non-flattering comments that learners make about people and characters and contexts are all filled with evaluative accents and the formative years of education ought to be directed at developing such enunciatory skills. 
Three indelible experiences remain etched on my mind:

1. I attended three international conferences: one at the University of the Free State, one in Botswana and the last one in China. I shall not report how on all three I presented my research-in-progress to enthusiastic audiences without any sponsorship from my university, even though Prof. massaged and negotiated me into believing that exposure to such communities of practice was more beneficial in terms of scholarship than what the university could offer financially.

2. In the final wrap-up of the thesis, I submitted four leatherbound copies and the administrative assistant in my faculty broke into hilarious laughter. 'Copies for external examination had to be spiral-bound, not this fancy work!' I had skipped the regulation in the Manual for Postgraduate Students and had to redo all the four copies at my own expense. I was Prof.'s first PhD student in English and he had thought the bound copies would be acceptable.

3. When the external reports came back, Prof. phoned me after 21:00 to say I should meet him. I raced from my school through the university gates and was at his door in minutes. He sat behind a stack of books and said: 'I am surprised all three external examiners think your dissertation should pass ... but there are corrections to be made ...'

If Prof. was surprised, I was shocked at his sense of dis-ownership of this research product. Did he not, all this time, think I was leavening and ripening as a researcher? I found solace in the second external examiner's report:

It was a delight to examine this insightful and inspiring thesis. The thesis addresses a very thorny problem of the lack of academic English proficiency among students for whom English is not the first language ... This study breaks new ground and brings new evidence to bear with regard to the challenges faced by multilingual students in monolingual English medium schools ... The thesis as a whole gives more than sufficient evidence of the requisite amount of originality for a doctoral study.

There is no future in history; doctorateness implies synergy and results from specific critical research features that constitute an interdependent network. For Motsha, this entailed reading, thinking, generating theoretical perspectives on the topic and engaging with massive literature in order to create coherent theoretical perspectives which in turn were the foundation for analysing findings. All these subsequently linked to the gap in knowledge to which the study contributed.

\section{Nepaps' journey}

Nepaps held a master's degree in Translation (English A French B) obtained from one of the most prestigious translation schools on the African continent. He had served as a translator with a few government departments and private companies in his country of origin and as a freelance translator.
In 2008, when Nepaps met Prof., considering his translation background, he hinted at his interest to work on multilingualism and multiculturalism considering the linguistic diversity of his country and the fact that the university did not have a translation programme at postgraduate level for his language combination. Having successfully defended his MA dissertation (a French-English glossary of terms relating to building finishing) and challenges encountered while serving as a translation consultant with the marketing department of one of the internet providers informed the need for Nepaps doctoral thesis.

After discussing with Prof. on the area of interest and what I had done in the past, it was agreed that I should tease out on multilingualism in advertising: the case of Douala-Cameroon. It was easy for us to agree on a working topic because these were areas of research interests for Prof. Nepaps was thus requested to submit a proposal for Prof. to dissect within a couple of months.

Nepaps submitted a proposal (25 pages) to Prof. After more than 2 months of waiting, I received a call from Prof. for us to meet in his office for feedback. He had read about 10 of the 25 pages of the proposal and requested that I prepare for a presentation at departmental level. My Prof. also informed me that he decided to request one of his colleagues to serve as a co-supervisor considering his workload. This was done without my consent. As a PhD candidate who wanted to see the completion of the study, I had not to 'dare tap my Sophocles on the back' as he held the key to my success.

Prof. arranged for a presentation at departmental level for inputs from lecturers. After attending to the suggestions and inputs from members of staff, I had to submit a revised copy of the proposal (40 pages). The proposal examined the language situation in the country, language planning and language policy, language management, the hegemony of French and English in advertising, advertising and semiotics, multilingual landscapes, language and power, suggestions on the need for advertising to be done in languages of wider communication and the benefits of multilingual and multicultural advertising.

Nepaps successfully presented the proposal at the Faculty's Higher Degrees Committee 6 months later and was given the green light to proceed with the study. After a year into the study, one of the members of the department (who also happened to be the head of department at the time) advised that I modify the topic to ensure that the qualification sells better upon completion. That is, doing a comparative study of Cameroon and South Africa to show that there was contribution in terms of knowledge for the host country. Considering the fact that I had already collected part of the data before this suggestion, the initial data collected had to be discarded. This, therefore, meant the allocation of more time for the process in order to meet the needs of the modified topic (Multilingualism in advertising: A comparative study of Cameroon and South Africa). 
The aim of the modified study was to provide strategic and policy directions which could impact positively on the current advertising landscape of the two countries reviewed. The study was also intended to add to the critical debate on advertising as it highlighted that multilingual advertisements lead to nation-building and that linguistic inequality in advertising impacts negatively a country's citizenry. Two methods of investigations were used in the study: a literature review and an empirical investigation using a qualitative approach supported by a minor component of quantitative research. I had to read extensively in order to be able to identify the gaps and make recommendations towards closing such gaps and make a contribution to existing knowledge. In the process, I consulted Ager's Motivation in Language Planning and Language Policy (2001), Cook's The Discourse of Advertising (1994), Cooper's Language Planning and Social Change (1989), Foucault's Power/Knowledge: Selected Interviews and Other Writings (1980), and Kelly-Holmes' Advertising as Multilingual Communication (2005), among others. All these gave me an insight into the discourse of advertising and communication but not the contribution of multilingual and multicultural advertising in society. This was thus the problem I had identified given the multilingual and multicultural nature of the countries under consideration.

While working on the literature review and theoretical framework, I was constantly reminded that there was no shortcut to a PhD and that I needed to go back to the field to collect new data that would correspond with the modified topic. At least, I needed some form of guidance in terms of feedback and feedforward in order to address the period of liminality that I was going through.

According to Granville and Dison (2009:53), 'feedback cannot be treated as a separate and isolated event that happens on the return of assignments; it needs to be part of a holistic and integrated programme: a continuous cycle of action, feedback and reflection so that students integrate what is taught in relation to the expected learning outcomes of a particular task'. Feedback with reflection is pivotal - the two processes form an important link between students' early experiences of a learning situation and the growth of understanding that is needed to make that learning meaningful (2009). The aim of feedback should, therefore, be to mould and not destroy the student. As the Prof., it is most likely that s/he should have been more exposed to academic writing than the novice researcher that I was. I expected constructive feedback to guide me along the journey. But when I received comments on the margins of my drafts and at times orally such as 'Your draft numbs me', 'Can I see your MA dissertation', 'Did you take a course in researcher methodology at Honours level?', 'I hope you are not planning to pull out the trigger?', and 'Some of the students and lecturers on campus are saying you will never finish because of the hands you fell into', I knew immediately that the road ahead was going to be very tough and treacherous. Paxton (1993:60) points to the fact that communication often breaks down in the feedback process. Comments such as 'your draft numbs me', 'Your draft lacks coherence' and 'Too many repetitions' struck
Nepaps as too abstract and vague for the candidate. Comments therefore should be 'text specific' and should give students 'clear and explicit strategies for revising their texts' (Granville \& Dison 2009:54). Parkerson (2000:127) argues for 'making the university culture explicit' and criticises the 'cryptic' comments that appear on essays or feedback given to students and researchers. Cryptic perhaps should also be extended to mean anagrammatic and puzzling.

Meyer and Niven (2007) focus on 'formative feedback', highlighting the notion that feedback should inform further application on the part of the students:

Feedback should be 'feed forward' - it should inform future drafts or tasks. It is assessment for rather than of learning. It should give constructive, realistic and staged advice on how to improve the next draft or assignment and on how to close the gap between what they wrote compared to an ideal answer. (p. 125)

This approach shifts the responsibility from the supervisor to the candidate to change and improve drafts in progress. Positive and constructive feedback is very important as it does not demoralise the students but pushes them to do more. Both oral and written feedback are necessary. All these were sorely absent during Nepaps' doctoral journey.

Lillis (2003:204) makes a distinction between 'feedback' and 'talkback'. According to Lillis, 'talkback' involves focusing on the student's text in process ... an attempt to open up the space where the student writer can say what they like and do not like about their writing. This notion is a very fitting and vivid way of expressing what one believes should happen during the feedback session. Reflection cannot be separated from dialogue (Granville \& Dison 2009:55). Through dialogue, the candidate is able to explain to the supervisor what they had in mind. Considering the fact that most, if not all, universities in South Africa do not have a viva voce session where candidates can present their final product, one may find examiners failing a thesis because one was not able to express himself or herself before a panel.

As a PhD candidate with two supervisors, one would have expected the two mentors to give one seamless stream of feedback to the candidate (collate feedback before giving it back to the candidate). The journey became long, tedious and strenuous because Nepaps never received unitary feedback. Nepaps received separate feedback from the two supervisors who would hardly sit down to look at their inputs and comments before calling the candidate.

To make matters worse, the volume of work to be handed in per submission was never decided upon. After submitting a chapter for marking, Nepaps had to wait for months before receiving feedback. And when Nepaps received a call to come over for feedback (which always happened late in the evening), to the researcher's dismay, only one and a half pages of the 20-page long chapter would have been marked. Nepaps was then advised to submit work in small bits (not more than two pages long at a time). The lack of a 
clear-cut method of working demoralised and delayed the progress of the candidate, generating a withdrawal syndrome, threatening to give up on the journey.

The journey dragged on for a couple of years, and when we thought the document was ready for submission, the co-supervisor (who had been co-opted by Prof.) indicated that the thesis could not be submitted for technical reasons (insufficient data, word limit not met, number of pages inadequate, a 'Reject' if the document were to go out for external examination). Nepaps had to wait another 12 months, improve on the data as suggested, fine-tune the thesis and do a spiral-bound copy for supervisors. The co-supervisor approved of the document as 'ready for submission', but Prof. insisted the analysis and presentation of findings were mere repetitions of the literature review. When I was called for feedback regarding the spiral-bound copy of the thesis I had been working on for years, about 20 pages of the work had been crossed over and by the margin there was the following comment for Nepaps' attention: 'Irrelevant, take to the literature review section'. Prof. insisted there were changes he had requested that I effect which I did not do. I was asked to bring all the drafts of my previous chapters (1-3) for confirmation if I had attended to all the suggestions made over the years. Thank my God I still had all the drafts I had kept in a lever arch file which my Prof. had insisted I buy in order to keep my feedback.

Prof. took a few days to go through the files to confirm if I actually attended to the suggestions he made. Convinced I had done as requested and after insisting that the thesis be submitted for examination, Prof. finally agreed to my request as I was completely burnt out. Then came the waiting period for examiners to assess the thesis and decide on Nepaps' fate. After some 7 months of waiting, all three examiners sent through their reports. Nepaps was called by Prof. to his office to look at the reports. After going through the reports, Prof. took a deep breath and said to Nepaps: 'It is amazing that the reports from all three examiners are very laudatory'. What were the expectations from the Prof.? A 'Reject' I suppose! I found solace in the recommendation of one of the external examiners: 'I recommend that the student be awarded the Doctor of Philosophy Degree in English. This comparative study makes a huge contribution to the use of multilingual advertising. The candidate was able to marshal his arguments in a scholarly manner'.

As Henry Wadsworth Longfellow remarks, 'the heights by great men reached and kept were not attained by sudden flight but, they while their companions slept, they were toiling upwards in the night'. The journey was long, tedious and stressful not because I was not 'doctoral' material but because of circumstances and the hands in which I fell into so to speak. Despite all the challenges, at the end, one should be able to reap the fruits of the hard work, which is the conferment of the degree.

\section{A word to future master's and doctoral candidates}

Makondo (2010:60) maintains that the first rule of thumb is that the more one writes, the easier writing becomes. M\&D students are thus advised to dedicate more time in writing short or long pieces for publication as this improves their writing skills and saves them the embarrassment that they might receive from promoters or supervisors.

Undertaking a PhD journey could be very challenging and demanding. However, it is instructive to pause for a moment and reflect on these taxing academic journeys. Once a student decides to undertake the journey to the academic pinnacle (or Permanent Head Damage), it is consoling to reflect on the Sisyphean and Promethean episodes of the punitive journeys.

According to Corbin and Strauss (2008:14), 'research itself is a process, one that ... students are likely to be self-reflective about. In doing their research, they enjoy the flow of ideas, but not merely the substantive ones since they have learned that theoretical ideas have their own precious value'. As a PhD candidate, it is assumed that one should have a proper mastery of theories and approaches connected to the field of study. This is not usually the case as students are sceptical of theories, however enticing they may seem, unless these are eventually grounded through active interplay with data.

M\&D students cannot complain that they lack material or information to assist them in their studies. There is abundance of literature on how to write clearly, and information on the topic under discussion. It is always assumed that after obtaining a master's degree and gaining admission into a $\mathrm{PhD}$, the candidate should be grounded in research. That is usually not the case and most universities do not offer research methodology courses at M\&D.

\section{Conclusion}

A doctoral degree is the pinnacle of academic achievement and it is expected that the effort should far outweigh the rewards. Journeying to the peak is more than an intellectual pilgrimage; it is also an emotional and psychological one. This article has demonstrated that sharing research histories through the diarist, auto/biographical narratives, allowed for interpretive refinements of perspectives about doctorateness. What emerged in the differently positioned research participants corroborates the observation that collaboration entails mobilising intellectual resources, that is, the ultimate product of research is invariably contingent on the teller, the research context and the myriad predicaments arising from conflict and contradiction both of which compel the urgency towards self-determination. This journeying requires commitment, perseverance and mental stamina (Roberts 2004:xv). 
A thesis creatively complicates orthodox prescriptions: it becomes a rewarding intellectual and academic experience that ought to be completed within set times. Students succeed in completing their theses when they get:

- One-on-one coaching.

- Cluster group tutorials.

- Have a forum for dissertation seminars and colloquia for presenting their woolly ideas stage-by-stage.

For Motsha and Nepaps, the research tasks were reflective and oppositional acts for empowerment. The reconfiguration of the relationships between two students and one supervisor is now some bittersweet aftertaste, and the 'doctorateness' quality now harps for exhibition. Perhaps, after all, doctorateness implies the constellation of strategic ways by which research processes are appropriated and negotiated to fashion voice that explores everyday problems. Each study is a share of Mount Everest: not the entire mountain can be moved, but the small samples resonate with some robust depth and rigour.

\section{Acknowledgements}

This article was in retrospect, funded by the generous bursaries disbursed to the authors while re-searching for doctoral studies.

\section{Competing interests}

The authors declare that they have no financial or personal relationship(s) that may have inappropriately influenced them in writing this article.

\section{Authors' contributions}

M.L.H. conceived the idea and the topic, and P.N.N. and M.L.H. contributed towards the writing of the article. P.N.N. submitted the manuscript.

\section{References}

Ager, D., 2001, Motivation in language planning and language policy, Cromwell Press Ltd, Clevedon.

Hove, M.L., 2014, Strategies of representation in auto/biography: Reconstructing and remembering, Palgrave MacMillan, Newcastle upon Tyne.

Batchelor, D. \& Di Napoli, R., 2006, 'The doctoral journey: Perspectives', Educate 6, 13-24.

Bakhtin, M., 1981, The dialogic imagination: Four essays, M. Holquist (ed.), transl. C. Emerson \& M. Holquist, University of Texas Press, Austin, TX.

Blommaert, J., 2005, Discourse: A critical introduction, Cambridge Approaches to Language Contact, Cambridge.

Blumer, H., 1969, Symbolic interactionism, Prentice Hall, Englewood Cliffs, NJ.
Brown, G. \& Atkins, M., 1988, Effective teaching in higher education, Routledge, London.

Canagarajah, S., 2006, Towards a writing pedagogy of shuttling between languages: Learning from multilingual writers, Routledge, London.

Cook, G.W.D., 1994, The discourse of advertising, Routledge, London.

Cooper, R.L., 1989, Language planning and social change, Cambridge University Press, Cambridge.

Corbin, J. \& Strauss, A., 2008, Basics of qualitative research: Techniques and procedures for developing grounded theory, Sage, Thousand Oaks, CA.

Creswell, J.W., 2013, Qualitative enquiry and research design: Choosing among the five approaches, Sage, Thousand Oaks, CA.

Cummins, J., 1994, 'The acquisition of English as a second language', in K. SpangenbergUrbschat \& R. Pritchard (eds.), Reading instruction for ESL students, pp. 17-29, International Reading Association, Newark, DE.

Delpit, L., 1995/2006, Other people's children: Cultural conflict in the classroom, The New Press, New York.

Foucault, M., 1980, Power/knowledge: Selected interviews and other writings 1972-1977, Pantheon Books, New York.

Freire, P., 1972/1996, Pedagogy of the oppressed, Penguin, New York.

Gee, J.P., 1990, Social linguistics and literacies: Ideology in discourses, Routledge, London.

Granville, S. \& Dison, L., 2009, 'Making connections through reflection: Writing and feedback in an academic literacy programme', Southern African Linguistics and Applied Language Studies 27(1), 53-63, viewed 23 March 2016, from http://dx. doi.org/10.2989/SALALS.2009.27.1.5.753

Janks, H., 2010, Literacy and power, Routledge, New York.

Kapp, C., 2014, The science and art of postgraduate supervision and assessment, Chris Kapp and Associates, viewed n.d., from www.chriskapp.co.za

Keefer, J.M., 2015, 'Experiencing doctoral liminality as a conceptual threshold and how supervisors can use it', Innovations in Education and Teaching International 52(1), 17-28. http://dx.doi.org/10.1080/14703297.2014.981839

Kelly-Holmes, H., 2005, Advertising as multilingual communication, Palgrave Macmillan, New York.

Lillis, T., 2003, 'Student writing as "academic literacies": Drawing on Bakhtin to move from critique to design', Language and Education 17(3), 201-221. http://dx.doi. org/10.1080/09500780308666848

Makondo, L., 2010, 'Demystifying research', in M.A. Mokoena \& L. Makondo (eds.), Fundamentals of scientific research and publishing, pp. 55-78, The Platinum Press, Potchefstroom.

McAleese, C. \& Welsh, J.M., 1983, 'Contested disciplinarity in international doctoral supervision', presented at the international conference on learning, Maastricht, The Netherlands, July 16-19, 1983.

Meyer, W. \& Niven, P., 2007, 'Critical reflections on the role of identity in two respondents' formative assessment practices', English Academy Review: Southern African Journal of English Studies 24(2), 121-133. http://dx.doi.org/10.1080/ 10131750701452352

Mignolo, W.D., 2015, 'Epistemic disobedience, independent thought and de-colonia freedom', Theory, Culture \& Society 26(7), 1-23.

Parkerson, A., 2000, 'Providing effective feedback on student writing', in B. Leibowitz \& Y. Mohammed (eds.), Routes to writing in Southern Africa, pp. 118-130, Silk Road International Publishers, Cape Town.

Paxton, M., 1993, 'Tutor responses to student writing', in S. Angelil-Carter (ed.), Language academic development at the University of Cape Town, pp. 54-67, UCT, Cape Town.

Phillipson, R., 1992, Linguistic imperialism, Oxford University Press, Oxford.

Ridge, S.G.M., 2015, 'Reflections on transformation and the role of the intellectual: A critical essay', English Academy Review 32(2), 132-144. http://dx.doi.org/10.1080/ 10131752.2015.1086163

Roberts, C.M., 2004, The dissertation journey: A practical and comprehensive quide to planning, writing, and defending your dissertation, Corwin Press, Thousand Oaks, CA.

Smitherman, G., 1977, Talkin' and Testifyin': The language of Black America, Wayne State University Press, Detroit, MI.

Turner, G., 2015, 'Learning to supervise: Four journeys', Innovations in Education and Teaching International 52(1), 86-98. http://dx.doi.org/10.1080/14703297.2014. 981840 